\title{
Identification of Group ' $E$ ' Chromosome Abnormalities in Human Cells
}

\author{
KATHARINE E. VAUSE and J. K. McDOUGALL \\ Department of Cancer Studies, University of Birmingham, The Medical School, Birmingham B15 2Tf \\ Summary. The specific adenovirus type- 12 induced aberration in chromosome \\ No. 17 has been used to identify this autosome in cells from patients with No. 17/18 \\ (E group) chromosome abnormalities. The results show that all the cases examined \\ involved abnormalities of chromosome No. 18.
}

Definite identification of the chromosome involved in E trisomy (Edward's syndrome; Edwards et $a l, 1960)$ and in various structural alterations of the $17 / 18$ autosomes has often been difficult on purely morphological grounds (Hamerton, 1971). Autoradiographic evidence that chromosome No. 18 completes synthesis later than No. 17 (Giannelli and Howlett, 1967) and that the extra chromosome in $\mathrm{E}$ trisomy is similarly late-replicating (Yunis, Hook, and Mayer, 1964) has supported Patau et al (1961) in defining this chromosome as a No. 18. This evidence was further supported by the demonstration that specific damage induced by adenovirus type 12 in chromosome No. 17 is only found in two of the five $17 / 18$ autosomes in E trisomy (McDougall, 1970).

A recent report by Bobrow and Pearson (1971) described the use of fluorescent chromosome staining (Caspersson et al, 1970) in the identification of E-group autosomes, although even in this highly successful method it was not possible to differentiate No. 17 from No. 18 in every cell. The recently described method of staining chromosomes with 'Giemsa', the 'ASG' technique (Sumner, Evans, and Buckland, 1971), has also provided a system of differentiation between the $17 / 18$ autosomes.

Results are presented in this report from studies with further cases involving E-group abnormalities, in which it has been possible to identify the chromosome involved in the aberration following virus infection in vitro.

\section{Methods}

Cells and Medium. Fibroblast cultures were established from skin biopsy samples taken aseptically

Received 7 July 1972. using the method recommended by Edwards (1960). The skin was cut into small pieces which were placed under a sterile glass coverslip in a 5-cm plastic Petri dish together with $5 \mathrm{ml}$ of F10 medium (Ham, 1963) supplemented with $10 \%$ tryptose phosphate broth (Difco) and $20 \%$ fetal calf serum (flow). The cultures were incubated at $37^{\circ} \mathrm{C}$ in a $5 \% \mathrm{CO}_{2}$ in air atmosphere. The cell outgrowths could be trypsinized after 2-3 weeks and reseeded into fresh dishes.

Virus. Adenovirus type 12 (Huie strain) was grown in human embryonic kidney (HEK) cells and purified by three successive centrifugations to equilibrium in caesium chloride (McDougall, Dunn, and Jones, 1972). The infectivity of the virus was calculated from titrations in HEK cells.

Cytogenetic Studies. Cells were seeded in $5-\mathrm{cm}$ plastic Petri dishes at $5 \times 10^{5}$ cells/dish in $5 \mathrm{ml}$ of medium. After 48 hours incubation at $37^{\circ} \mathrm{C}$ the monolayers were washed twice with phosphate-buffered saline (PBS) and infected by absorbing $2 \times 10^{6}$ infectious units (plaque forming units) of adenovirus type 12, in $0.2 \mathrm{ml}$ of PBS, for 3 hours at $37^{\circ} \mathrm{C}$. After the adsorption period the monolayers were washed with PBS before adding $5 \mathrm{ml}$ of medium and re-incubating at $37^{\circ} \mathrm{C}$ for 24 hours. At 23 hours post-infection $0.5 \mathrm{ml}(0.02 \%)$ colchicine was added to each culture to arrest cells in metaphase. The procedure for making chromosome preparations at 24 hours post-infection has already been described (McDougall, 1970).

\section{Results}

The chromosomes of 100 virus-infected cells and 100 uninfected cells were examined from each of four cases of $\mathrm{E}$ trisomy syndrome-one case with a deletion of the short arms of an $\mathrm{E}$ group chromosome $(46, \mathrm{XY}, \mathrm{Ep}-)$, one case with a ring $\mathrm{E}$ group chromosome $(46, \mathrm{XY}, \mathrm{Er})$, and one case which had 


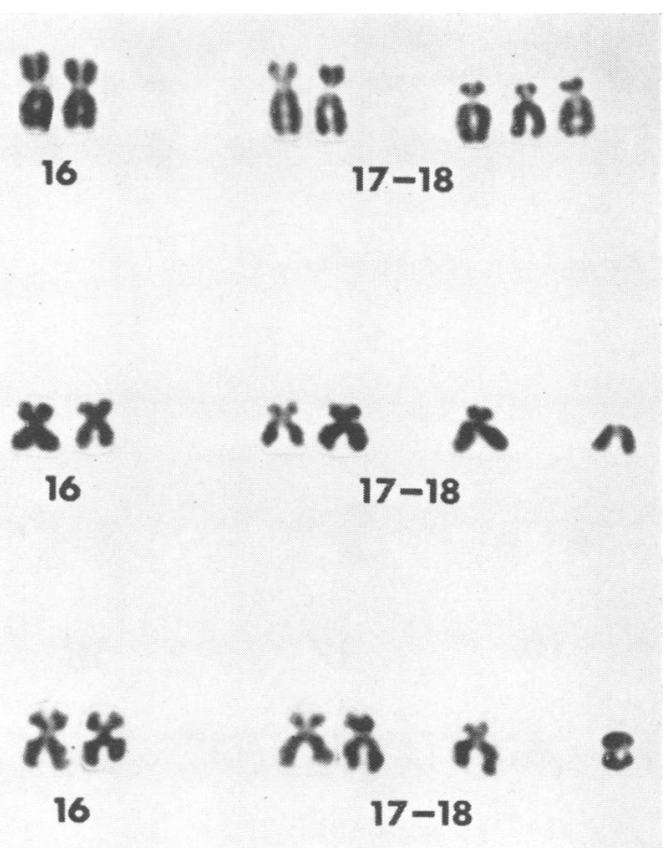

Fig. 1. E group chromosomes from cultured skin fibroblasts of case 1 (E trisomy), case 5 (Ep - ), and case 7 (E ring).

two lines of cells, one with a short arm deletion of an $E$ group chromosome and one with a ring $E$ chromosome (46,XX,Er/46,XX,Ep - ). One hundred infected cells and 100 uninfected cells were also examined from a male control $(46, \mathrm{XY})$ and a female control $(46, \mathrm{XX})$.

Representative E group chromosomes from the three types of cytogenetic abnormality are shown in Fig. 1. The effects of adenovirus type 12 on the $17 / 18$ chromosomes of these cases are summarized in Table I. It can be seen that the virus induces specific damage to two $\mathrm{E}$ group chromosomes in a high proportion of cells from all these cases. The site of the aberration is consistently in the same position on the long arms of this chromosome (Fig. 2). As in the two cases previously reported (McDougall, 1970), the specific virus-induced lesion was never found in more than two autosomes in any cell from the $\mathrm{E}$ trisomy cases.

The numbers of cells from cases 5,6 , and 7 with damage to two $17 / 18$ autosomes are shown in Table II. E group chromosomes from the present series of cases, following infection in vitro of cultured skin fibroblasts with adenovirus type 12, are shown in Fig. 3.

\section{Discussion}

It has been shown that adenovirus type 12 causes highly specific lesions at a locus on chromosome No. 17 (zur Hausen, 1967; McDougall, 1970, 1971a, and $1971 \mathrm{~b})$. Further confirmation of this specificity is given by the fact that the two $\mathrm{E}$ group autosomes with adenovirus-12 specific damage have the typical banding pattern of No. 17 chromosomes when stained by the 'ASG' method (Fig. 4).

The precise nature of the virus-induced aberration

TABLE I

ABERRATIONS IN 17/18 (GROUP E) CHROMOSOMES FOLLOWING IN-VITRO INFECTION WITH ADENOVIRUS TYPE 12

\begin{tabular}{|c|c|c|c|c|c|c|c|c|}
\hline \multirow{3}{*}{$\begin{array}{l}\text { Case } \\
\text { No. }\end{array}$} & \multirow{3}{*}{$\begin{array}{l}\text { Chromosome } \\
\text { Constitution }\end{array}$} & \multicolumn{7}{|c|}{ Cells with Chromosome and Chromatid Gaps and Breaks } \\
\hline & & \multicolumn{4}{|c|}{ Infected with Adenovirus-12* } & \multicolumn{3}{|c|}{ Uninfected* } \\
\hline & & Total & $\begin{array}{c}1 \text { or } 2 \\
\text { E-group } \\
\text { Chromosomes }\end{array}$ & $\begin{array}{c}>2 \\
\text { E-group } \\
\text { Chromosomes }\end{array}$ & $\begin{array}{c}\text { Abnormal } \\
\text { Chromosome }\end{array}$ & Total & $\begin{array}{l}\text { E-group } \\
\text { Chromosomes }\end{array}$ & $\begin{array}{l}\text { Abnormal } \\
\text { Chromosome }\end{array}$ \\
\hline 1 & $47, \mathrm{XY}, \mathrm{E}+$ & 23 & 8 & 0 & NAt & 2 & 0 & - \\
\hline 2 & $47, \mathrm{XX}, \mathrm{E}+$ & 9 & 4 & 0 & NA & 1 & 0 & - \\
\hline 3 & $47, \mathrm{XX}, \mathrm{E}+$ & 12 & 5 & 0 & NA & 3 & 0 & - \\
\hline 4 & $47, \mathrm{XX}, \mathrm{E}+$ & 24 & 10 & 0 & NA & 5 & 0 & - \\
\hline 5 & 46,XY,Ep - & 27 & 13 & 0 & 0 & 4 & 0 & 0 \\
\hline 6 & 46,XY,Er & 23 & 8 & 0 & 0 & 2 & 0 & 0 \\
\hline 7 & $46, \mathrm{XX}, \mathrm{Er} / \mathrm{Ep}-$ & 38 & 18 & 0 & 0 & 12 & 0 & 0 \\
\hline 8 & $46, \mathrm{XX}$ & 49 & 30 & 0 & NA & 0 & 0 & - \\
\hline 9 & $46, X Y$ & 56 & 32 & 0 & NA & 2 & 0 & - \\
\hline
\end{tabular}

* One hundred cells analysed for each case.

† NA = not applicable. 


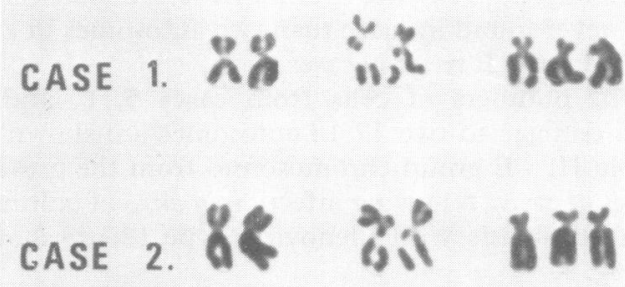

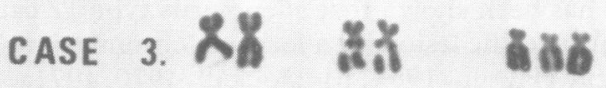

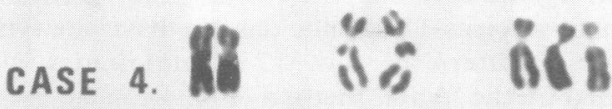

CASE 5. ก้กั นั้ ถัก

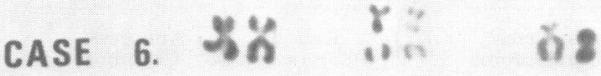

CASE 7.88 :

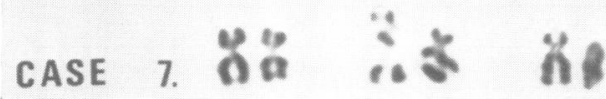

FIG. 3. E group chromosomes from seven subjects with abnormalities of chromosome 18 . The No. 17 autosomes are identified by the specific aberration induced by adenovirus type 12 .

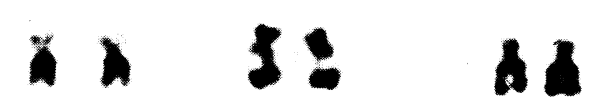

16

17

18

Fig. 4. E group chromosomes from adenovirus-12 infected cell stained by ASG technique (Sumner et al, 1971).

TABLE II

SPECIFIC ABERRATIONS INDUCED BY ADENOVIRUS TYPE 12 IN THE NO 17 CHROMOSOMES OF CELIS WITH STRUCTURAL ABNORMALITIES IN THE E GROUP

\begin{tabular}{c|c|c|c}
\hline \multirow{2}{*}{$\begin{array}{c}\text { Case } \\
\text { No. }\end{array}$} & $\begin{array}{c}\text { Chromosome } \\
\text { Constitution }\end{array}$ & \multicolumn{2}{|c}{$\begin{array}{c}\text { Specific Virus-induced } \\
\text { Aberrations in Cells: }\end{array}$} \\
\cline { 3 - 4 } & & One No. 17 & Both No. 17s \\
\hline 5 & $46, X Y, E p-$ & 6 & 7 \\
6 & $46, X Y, E r$ & 5 & 3 \\
7 & $46, X X, E r$ & 4 & 10 \\
& $46, X X, E p-$ & 2 & 2 \\
\hline
\end{tabular}

on chromosome No. 17 is not known, but the possibility that it represents an uncondensed sequence of DNA involved in the synthesis of an enzyme required by the virus has already been suggested (McDougall, 1971a). Kit, Nakajima, and Dubbs (1970) have shown that the thymidine kinase induced by adenovirus is host-specified and that the virus does not induce this enzyme in cells deficient in thymidine kinase. Boone, Chen, and Ruddle (1972) have recently confirmed the earlier reports assigning the locus for thymidine kinase in human cells to chromosome No. 17 (Migeon and Miller, 1968; Boone and Ruddle, 1969) and have further shown that the locus is probably on the long arm of this chromosome. This virus-induced damage allows for unequivocal identification of this chromosome and consequently a conclusion can be reached regarding the involvement of either No. 17 or No. 18 in numerical and structural abnormalities. 
From the results shown in Tables I and II and in Fig. 3, it can be seen that it was possible to identify two No. 17 autosomes in the cells of each case. It can therefore be concluded that in each of the cases examined the extra or abnormal chromosome was found to be a No. 18. An examination of cases involving E-group abnormalities reported in the literature (Polani, 1969; Hamerton, 1971) suggests that the chromosome involved is usually described as a No. 18 or as an undefined $17 / 18$. Those reports, taken together with the results presented here, offer evidence in support of the hypothesis that all abnormalities described as $17 / 18$ are in fact of No. 18 and that abnormalities of chromosome No. 17 are not compatible with continued survival of the embryo. Such a conclusion would obviously assist attempts at 'mapping' chromosome No. 18, where clear identification is vital (Hamerton, 1971).

We are grateful to Professor J. H. Edwards (cases 1-4) and Dr F. J. W. Lewis (cases 5-7) for skin biopsy samples and to Professor D. G. Harnden for his advice. This work was supported by the Cancer Research Campaign.

\section{REFERENCES}

Boone, C. M., Chen, T. R., and Ruddle, F. H. (1972). Assignment of three human genes to chromosomes (LDH-A to 11, TK to 17 and IDH to 20) and evidence for translocation between human and mouse chromosomes in somatic cell hybrids. Proceedings of the National Academy of Sciences of the United States of America, 69, 510-514.

Boone, C. M. and Ruddle, F. H. (1969). Interspecific hybridization between human and mouse somatic cells: Enzyme and linkage studies. Biochemical Genetics, 3, 119-136.

Bobrow, M. and Pearson, P. L. (1971). The use of quinacrine fluorescence in the identification of $\mathrm{B}$ and $\mathrm{E}$ group chromosomes involved in structural abnormalities. Fournal of Medical Genetics, 8, 240-243.

Caspersson, T., Zech, L., Johansson, C., and Modest, E. J. (1970). Identification of human chromosomes by DNA-binding fluorescent agents. Chromosoma, 30, 215-227.

Edwards, J. H. (1960). Painless skin biopsy. Lancet, 1, 496.

Edwards, J. H., Harnden, D. G., Cameron, A. H., Crosse, V. M., and Wolf, O. H. (1960). A new trisomic syndrome. Lancet, 1, 787-789.

Gianelli, F. and Howlett, R. M. (1967). The identification of the chromosomes of the E Group (16-18 Denver): an autoradiographic and measurement study. Cytogenetics, 6, 420-435.

Ham, R. G. (1963). An improved nutrient solution for diploid Chinese hamster and human cell lines. Experimental Cell Research, 29, 515-526.

Hamerton, J. L. (1971). Human Cytogenetics, vol. 2, pp. 276-309. Academic Press, New York and London.

Kit, S., Nakaiima, K., and Dubbs, D. R. (1970). Origin of thymidine kinase in adenovirus-infected human cell lines. fournal of Virology, 5, 446-450.

McDougall, J. K. (1970). Effects of adenoviruses on the chromosomes of normal human cells and cells trisomic for an E chromosome. Nature, 225, 456-458.

McDougall, J. K. (1971a). Spontaneous and adenovirus type 12induced chromosome aberrations in Fanconi's anaemia fibroblasts. International fournal of Cancer, 7, 526-534.

McDougall, J. K. (1971b). Adenovirus-induced chromosome aberrations in human cells. Fournal of General Virology, 12, 4351.

McDougall, J. K., Dunn, A. R., and Jones, K. W. (1972). In situ hybridization of adenovirus RNA and DNA. Nature, 236, 346348.

Migeon, B. R. and Miller, C. S. (1968). Human-mouse somatic cell hybrids with single human chromosome (Group E): link with thymidine kinase activity. Science, 162, 1005-1006.

Patau, K., Therman, E., Smith, D. W., and Demars, R. I. (1961). Trisomy for chromosome no. 18 in man. Chromosoma, 12, 280285.

Polani, P. E. (1969). Autosomal imbalance and its syndromes excluding Down's. British Medical Bulletin, 25, 81-93.

Sumner, A. T., Evans, H. J., and Buckland, R. A. (1971). A new technique for distinguishing between human chromosomes. Nature New Biology, 232, 31-32.

Yunis, J. J., Hook, E. B., and Mayer, M. (1964). Deoxyribosenucleic-acid replication pattern of trisomy-18. Lancet, 2, 286-287.

Zur Hausen, $H$. (1967). Induction of specific chromosomal aberrations by adenovirus type 12 in human embryonic kidney cells. fournal of Virology, 1, 1174-1185. 